\title{
MÉLYHÚZÁS VÉGESELEMES MODELLEZÉSÉNEK TECHNOLÓGIAI ÉS ELMÉLETI FELHASZNÁLÁSA
}

\section{TECHNOLOGICAL AND THEORETICAL APPLICATION OF FINITE ELEMENT MODELING OF DEEP DRAWING}

\author{
Bertók Ádám ${ }^{1}$, Gonda Viktor², Széll Károly ${ }^{3}$ \\ 1,2Óbudai Egyetem Bánki Donát Gépész és Biztonságtechnikai Mérnöki Kar, \\ 1081 Budapest, Népszínház utca 8. \\ ${ }^{3}$ Óbudai Egyetem, Alba Regia Müszaki Kar, 8000 Székesfehérvár, Budai út 45. \\ 1adambertok94@gmail.com; ${ }^{2}$ gonda.viktor@bgk.uni-obuda.hu
}

\begin{abstract}
For metal forming problems, even for a simple forming technology, finite element analysis can provide a solution for calculating deformations, determining stress and strain distributions. The aim of this study is to create a parametric finite element model for deep drawing technology, by which technological optimization as well as theoretical problems can be solved. By performing parameter studies, numerous cases can be analyzed.
\end{abstract}

Keywords: metal forming, finite element modeling, deep drawing.

\section{Összefoglalás}

A képlékeny alakítási feladatok esetén még az egyszerübb technológiák vizsgálatánál is nagy segítséget nyújt a végeselemes modellezés az alakváltozások és feszültségek analíziséhez. Célunk a mélyhúzás technológiájára vonatkozóan egy olyan végeselemes alapmodell megalkotása volt paraméteresen, aminek a segítségével technológiai és elméleti problémák is megoldhatóvá válnak, a paraméterek változtatásával könnyen és gyorsan több eset vizsgálata is lehetővé válik.

Kulcsszavak: képlékeny alakítás, végeselemes modellezés, mélyhúzás.

\section{Bevezetés}

A mélyhúzás az egyik legelterjedtebben alkalmazott lemezalakító müvelet, mely során a sík lemezböl üreges test állítható elö. A mélyhúzás technológiájának vizsgálatánál is nagy segítséget nyújt a végeselemes modellezés az alakváltozások és feszültségek analíziséhez, és ezekből származtatható technológiai paraméterek számításához. Célunk a mélyhúzás technológiájára vonatkozóan egy olyan végeselemes alapmodell megalkotása volt paraméteresen, aminek a segítségével tech- nológiai és elméleti problémák során elöforduló paramétervizsgálatok könnyen elvégezhetők. Jelen dolgozatban a tengelyszimmetrikus végeselemes modell felépítését, mutatjuk be, majd a modell felhasználását egyrészt egy technológia tervezési példán keresztül, másrészt pedig az elméleti húzási fokozat becslésén keresztül, melyhez a csészehúzó vizsgálat modellezését használtuk fel.

\section{A végeselemes modell felépítése}

Az alapmodellt ráncgátló nélküli mélyhúzás szimulációjához készítettük, ahol 
bélyeg, matrica és a teríték található meg, melynek elméleti vázlata az 1 . ábrán látható. A bélyeg és a matrica lekerekítési sugarait tervezési segédletben ajánlott optimális értékek közé vettük [1].

A modellezéshez a MSC MARC Mentat programot használtuk. Ahhoz, hogy a végeselemes szimulációt elvégezhessük, elöször a vizsgálni kívánt modell geometriáját kellett megalkotnunk. A tengelyszimmetriát kihasználva síkbeli modellt hoztunk létre (2. ábra). Az alapmodellt paraméteresen építettük fel, így elősegítve a későbbi könnyebb felhasználhatóságot.

A lemezt rugalmas-képlékenynek keményedőnek modelleztük. Az a lemez anyagát a modellben DC03-as minőségü lemezacélnak adtuk meg. Táblázatos formában adtuk meg a folyásgörbe függvényét a lemez anyagára vonatkozóan. A tengelyszimmetrikus modellben az anyagot izotrópnak tekintettük. A szerszámelemeket merevnek modelleztük. A mozgó szerszámelemhez, azaz a bélyeghez, táblázatos formában egy egyszerü lineáris függvényt rendeltünk hozzá, amivel a szerszámmozgás időfüggvényét írtuk le.

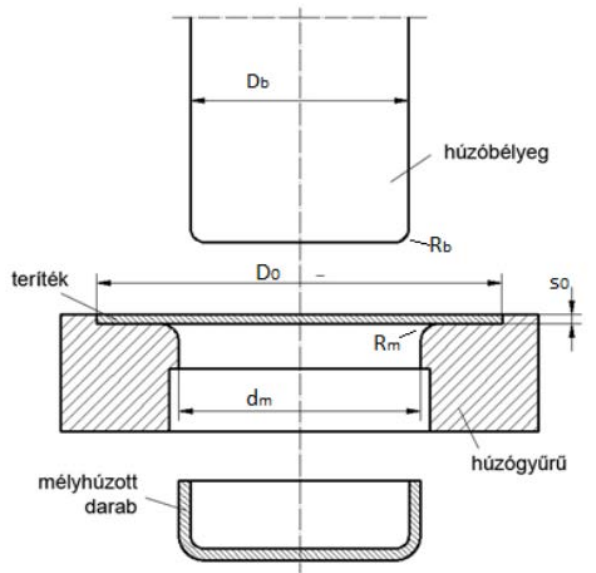

1. ábra. Mélyhúzás elméleti vázlata

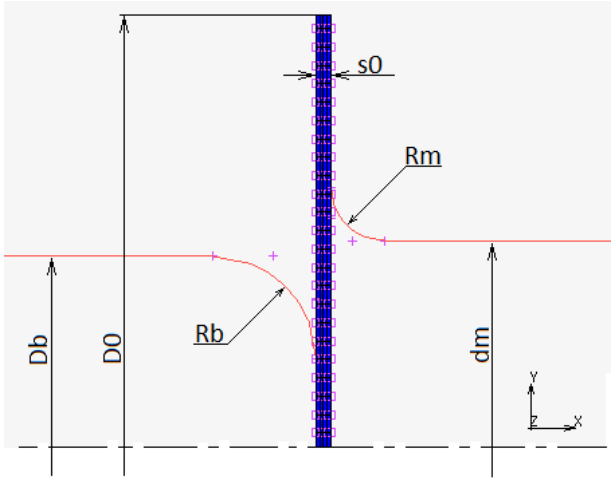

2. ábra. A végeselemes modell felépitése

A modell megalkotásával párhuzamosan egy úgynevezett eljárás (procedure) fájlt is létrehoztunk azért, hogy az alapprogramunkat könnyebben tudjuk aktualizálni a konkrét feladatokhoz. Ezzel könynyedén módosíthattunk a geometrián, továbbá felgyorsította az eredmények kiértékelését.

\section{A modell alkalmazása}

\subsection{Technológia tervezés}

A kiinduló esetben a terítékátmérőt $\mathrm{D}_{0}=$ $82,5 \mathrm{~mm}$, a bélyeg átméröjét pedig $D_{\mathrm{b}}=27$ mm értékkel modelleztük. A számítást lefuttatva, az eredményeket vizsgálva látható, hogy a peremet ezzel a geometriával nem lehet teljesen behúzni, a csésze palástjának fenékhez közeli részén található elem megnyúlik, majd elkezd vékonyodni, a valóságban a fenék leszakadása itt megtörténik (3. ábra). A perem behúzásakor annak anyaga felkeményedett, ezáltal a behúzásához szükséges erő úgy megnött, hogy a fenék közelében a palást már nem tudta ezt átvinni, a perem „rögzült”. A fenék leszakadna, de a szimulációban nincs tönkremeneteli feltétel, ezért a perem irreális vékonyodását figyelhettük meg. 


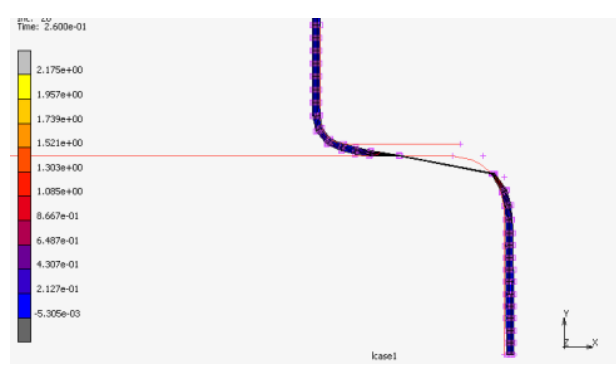

3. ábra. Fenékleszakadás esete

Ezt az esetet az elméleti húzhatósági határnak tekinthetjük és meg kell különböztetnünk attól a fenékleszakadástól, ami a behúzás során ébredhet, amikor a palástban a feszültség eléri a szakítószilárdságot.

A következő próbánál növeltük az alakítandó csésze belső átmérőjét $\mathrm{D}_{\mathrm{b}}=49 \mathrm{~mm}$ re, ezzel együtt a matrica átmérőjét is növeltük, de a többi geometriai adaton (húzórés, lekerekítések) nem változtattunk.

A szimulációt lefuttatva, a perem behúzása megtörtént. Itt számítható a húzási fokozat (egyszerüsített számítással a bélyegátmérő és terítékátmérő hányadosaként):

$$
\boldsymbol{m}=\frac{D_{b}}{D_{0}}=\frac{49}{82.5}=0.59
$$

Ezt követően különböző technológiai adatokat vizsgáltunk meg. Ilyen a húzás erő karakterisztikája. Ehhez a bélyeg erő-út diagramját kirajzoltattuk (4. ábra). Az ábráról leolvasott maximális erőigény:

$$
F_{\max }=25570 \mathrm{~N}
$$

A fenékleszakadáshoz tartozó kritikus erő $\left(\mathrm{F}_{\text {krit }}\right)$ ebben az esetben becsülhető az alábbi képlettel:

$$
F_{k r i t}=A \cdot R_{m}=25658 \mathrm{~N}
$$

ahol:

- A: a palást keresztmetszeti felülete $\left[\mathrm{mm}^{2}\right]$,

- $R_{\mathrm{m}}$ : szakítószilárdság, 330 [MPa].

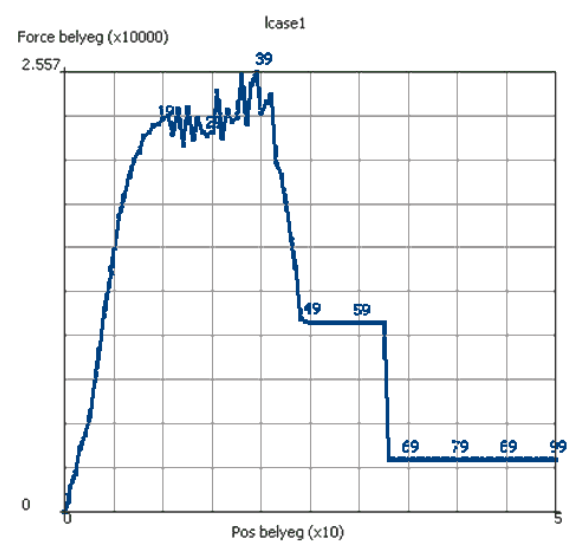

4. ábra. $A$ mélyhúzás erőkarakterisztikája $\left(D_{0}=\right.$ $82,5 \mathrm{~mm} ; D_{b}=49 \mathrm{~mm}$ )

Mivel:

$$
F_{\text {max }}<F_{\text {krit, }}
$$

ezzel a paraméter kombinációval elvégezhető a húzás.

Az elvégzett vizsgálatokkal a technológiai tervezés egy lehetséges megoldását mutattuk be.

\subsection{Csészehúzó vizsgálat}

A csészehúzó vizsgálat a mélyhúzás technológiai próbája. A vizsgálatot az MSZ 5731 szabvány írja le [2]. A vizsgálat tulajdonképpen kísérleti húzásnak tekinthető. Az 5. ábrán a csészehúzó vizsgálat modelljét láthatjuk.

A vizsgálat elvégzésének a menete, hogy egy adott lemezanyagra vonatkozóan, abból több különböző átmérőjü terítékkel elvégezzük a mélyhúzó próbát, és meghatározzuk azt a legnagyobb csészeátmérőt, ami még károsodás nélkül kihúzható. A vizsgálatból a húzási fokozat számítható, így jellemezhető az adott vastagságú, adott anyagú lemez mélyhúzhatósága. 


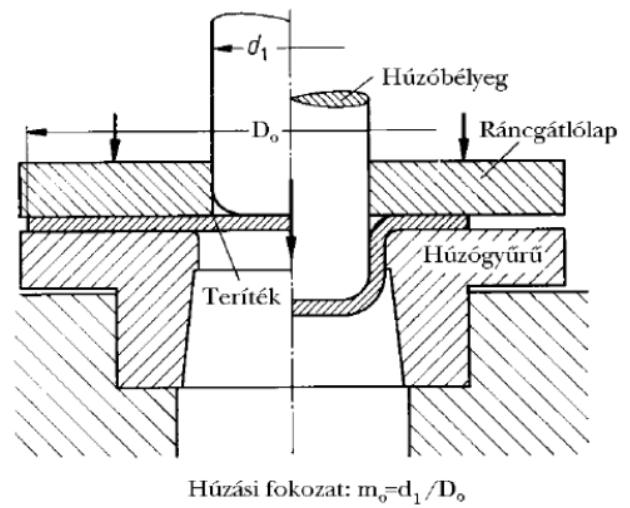

5. ábra. A csészehúzó vizsgálat sematikus ábrája

1. táblázat. Az csészehúzó vizsgálat szimulációjának eredményei a két lemezvastagságra

\begin{tabular}{|c|c|c|}
\cline { 2 - 3 } \multicolumn{1}{c|}{} & $\begin{array}{c}\text { Még húzható } \\
\text { átmérô }\end{array}$ & $\begin{array}{c}\text { Húzási foko- } \\
\text { zat }(\mathrm{m})\end{array}$ \\
\hline Vékony lemez & $68 \mathrm{~mm}$ & 0,49 \\
\hline Vastag lemez & $66 \mathrm{~mm}$ & 0,5 \\
\hline
\end{tabular}

A vizsgálat modellezésével az elméleti húzási fokozat értéke becsülhető egy adott folyási görbével rendelkező, adott vastagságú lemezanyagra vonatkozóan.

A vizsgálat modellezését egy adott anyagminőségü, két különböző vastagságú (0,5 mm; 3 mm) lemezzel végeztük el. Előzetes várakozásunk az, hogy a vastagabb lemez jobb húzhatósággal rendelkezik ezért nagyobb terítékátmérő lesz behúzható.

A csészehúzó vizsgálat szimulációjának eredményei a két lemezvastagságra az $\mathbf{1}$. táblázatban láthatók. Az eredmények alapján a várakozással ellentétesen a vékonyabb lemez bizonyult jobban húzhatónak, mivel itt nagyobb a még behúzható terítékátmérő. Ennek oka a húzás során a perem nagymértékü megvastagodása a 3 mm-es terítés esetében, mely a mély csésze esetén olyan mértékü, hogy az anyag kitölti a húzórést, sőt a perem vasalása is létrejön. Ez jól megfigyelhető a 3 mm-es lemez csészehúzásának szimulációja során (5. ábra). Továbbá érdemes még az éppen húzható átmérők esetén a bélyegre ható erőket megvizsgálni, az erőkarakterisztika csúcsosodása jól mutatja a vasaláshoz szükséges erő többlet megjelenését (7. ábra).

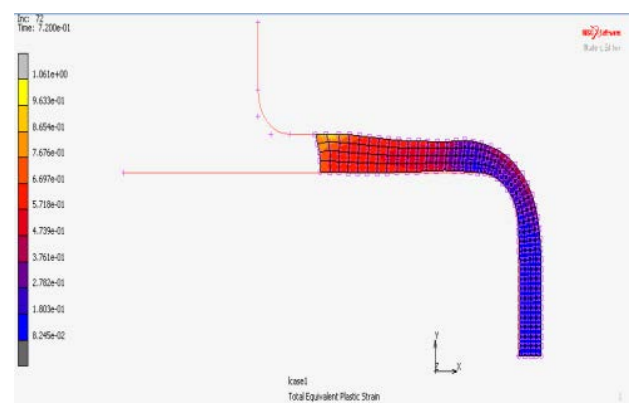

6. ábra. A perem vasalása

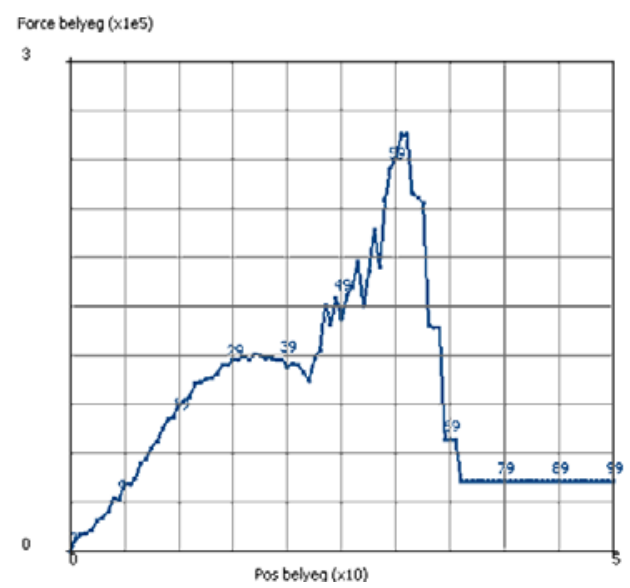

7. ábra. A bélyegerö a 3 mm-es lemez behúzása során

\section{Köszönetnyilvánítás}

A szerzők köszönetüket fejezik ki az Emberi Erőforrások Minisztériuma ÚNKP17-I-OE-779/15 pályázati támogatásának, valamint az EFOP-3.6.1-16-2016-00010 pályázati támogatásnak.

\section{Szakirodalmi hivatkozások}

[1] Horváth László: Mélyhúzás technológia tervezése, Oktatási segédlet, Óbudai Egyetem, 2009.

[2] Sárvári József: Képlékeny hidegalakítás. Nemzeti Tankönyvkiadó. 